https://doi.org/10.52240/1857-2367.2020.2(21).38

\title{
INTRODUCEREA PLANTELOR DIN GENUL SANSEVIERIA THUNB. ÎN GRĂDINA BOTANICĂ NAŢIONALĂ (INSTITUT) „ALEXANDRU CIUBOTARU"
}

\author{
Daniela CIOBANU \\ Grădina Botanică Naţională (Institut) ,Al. Ciubotaru”, \\ Chișunău, Republica Moldova
}

\begin{abstract}
The genus Sansevieria is very diverse and interesting in terms of life forms and shapes and enjoys great popularity among both botanists and plant lovers, who in recent years have become increasingly interested in these plants due to their decorativeness. In the Botanical Garden, this genus is represented by 27 taxa.
\end{abstract}

Key words: Genus, species, cultivar, collection, Sansevieria, hardiness, ornamental plants.

Genul Sansevieria Thunb. (familia Dracaenaceae Salysbury) include cca 60 specii de plante ierboase perene şi semiarbuşti cu rizom scurt şi gros, deseori cu drajoni, originare din regiunile tropicale ale Africii de Sud şi Asia (India, Şri-Lanca). După forma frunzelor, speciile se divizează în 2 grupuri: cu frunze cilindrice $(S$. gracilis N. E. Br., $S$. cylindrical W. Bojer) şi cu frunze plate (S. trifasciata Prain cu toate varietăţile şi cultivarurile, $S$. grandis Hook. etc.) [2]. Frunzele sunt rigide, cărnoase, erecte, culoarea lor variază de la verde-intens, cu striuri albe, dispuse transversal, cu margini galbene etc. Talia plantelor variază de la cele mai mici (S. trifasciata cv. Golden Hahnii) de cca 12 $\mathrm{cm}$, la cele mai mari - de la $70 \mathrm{~cm}$ (S. trifasciata cv. Futura superba), până la $115 \mathrm{~cm}$ la $S$. trifasciarta. Cele mai înguste frunze (de $1,5 \mathrm{~cm})$ se întâlnesc la $S$. caespitosa Dtr., $S$. volkensii Gurke, cele mai late frunze $(15 \mathrm{~cm})$ la $S$. grandis Hook.

Plantele acestui gen au fost introduse în colecția de plante suculente a GBN(I) 
„Al. Ciubotaru” începând cu anii 70 ai sec. XX din Grădinile Botanice din Rusia, Ukraina [1] și se bucură de o mare popularitate, fiind plante rezistente, decorative, cu potențial adaptiv înalt, recomandate pentru amenajarea birourilor, apartamentelor și caselor. Inițial, colecția cuprindea 6 specii, iar pe parcursul anilor s-a completat şi în prezent numără 27 de taxoni.

Sansevieria trifasciata Thunb. în colecţie este prezentă prin 11 cultivaruri de la cele mai scunde, până la cele mai înalte. Plantele formează în pământ rădăcini cărnoase, portocalii (asemănătoare unor rizomi), prevăzute cu muguri precum şi cu rădăcini secundare, ramificate, subţiri. Din mugurii de pe rădăcini pornesc frunze lanceolate, lungi de până la 1,2 m, groase, rigide, cărnoase, colorate în verde închis, pătate cu benzi transversale, gri-argintii. Acestea sunt sesile şi grupate câte două sub forma unui lăstar aparent, cu baza scurtă, nudă. Primăvara plantele mature formează flori tubuloase, verzi sau alb-verzui, reunite în raceme terminale, lungi de $30-75 \mathrm{~cm}$. Se cunosc mai multe varietăţi, diferenţiate între ele prin caracterele frunzelor: 'Lauretii' frunzele sunt bordate cu galben; 'Golden Hahnii' - plantă cu înălţimea de numai $20 \mathrm{~cm}$, are o creştere compactă, frunze verzi-argintii, larg bordate cu galben, groase, cărnoase, dispuse strâns în spirală ca într-o rozetă.

Sansevieria cylindrica Bojer - plantă cu frunze cilindrice rigide, uşor arcuite, vârful ascuţit, lungi de până la $1,5 \mathrm{~m}$, colorate în verde-închis cu dungi transversale verzi deschis. Florile sunt tubuloase, albe sau roz, lungi de 1,5-2,5 cm, grupate în raceme terminale spiciforme susţinute pe tije lungi de $35-75 \mathrm{~cm}$.

Sansevieria grandis Hook. f. se deosebește prin frunzele sale foarte late $(15 \mathrm{~cm}$.).

Ca rezultat al observaţiilor fenologice s-a stabilit că din 27 de taxoni înfloresc doar 12 specii, iar fructe cu seminţe formează 5 , motivul fiind lipsa de polenizatori. În ultimii ani Sansevieria a devenit un gen de plante tot mai solicitat pentru înverzirea spațiilor închise, fiind unul dintre cele mai rustice genuri de plante de interior, tolerând foarte bine atât soarele direct, cât şi umbra. Preferă temperaturile ridicate, de peste $+20^{\circ} \mathrm{C}$, suportă bine şi temperaturile mai scăzute, de până la $+8(10){ }^{\circ} \mathrm{C}$. Suportă bine absenţa apei însă este deosebit de sensibilă la excesul de umezeală care determină putrezirea rapidă a bazei plantei, tolerează, de asemenea, foarte bine aerul uscat, specific locuinţelor. În condiții de seră, Sansevieria se înmulţeşte foarte uşor primăvara, prin divizarea tufei, în diviziuni care cuprind minim 3-4 frunze şi rădăcinile aferente.

Sansevieria este genul de plante purificatoare cu capacităţi de a elimina din aerul încăperii toluenul, xilenul și formaldehida - substanțele nocive pentru om.

Cercetările sunt realizate în cadrul proiectului „Cercetări privind mobilizarea diversitătii vegetale cu potenţial ornamental pentru conservarea ex-situ”.

\section{BIBLIOGRAFIE}

1. К. Ф. Дворянинова, В. И. Шестак Тропические и субтропические растения в оранжереях Ботанического Сада ан МССР, Кишинев, Штиинца, 1985, стр. 42-43.

2. С. Г. Сааков. Оранжерейные и комнатные растения и уход за ними Москва „Наука”, 1985, стр. 94-96 